\title{
Age- and sex-related reference ranges for eight plasma constituents derived from randomly selected adults in a Scottish new town
}

\author{
MARY D GARDNER AND R SCOTT \\ From the Departments of Biochemistry and Urology, Glasgow Royal Infirmary, UK
}

SUMMARY The results of analysis of blood specimens from randomly selected adults aged 19-88 years in the new town of Cumbernauld were used to establish age- and sex-related reference ranges by the centile method (central $95 \%$ ) for plasma calcium, phosphate, total protein, albumin, globulins, urea, creatinine, and urate. The possible existence of a subpopulation with a higher reference range for urea is mooted.

During the past two decades there has been an increasing awareness of the many factors that influence the plasma level of commonly determined constituents; of these, age and sex play a major role. Many hospital laboratories still quote 'normal ranges' not so related, but, ideally, results should be referred to a population whose status is defined. ${ }^{1-3}$ The Cumbernauld Health Survey, ${ }^{4}$ which was undertaken to establish the prevalence of renal calculus disease in a random population, gave us the opportunity to carry out selected biochemical measurements on about 4000 adults.

\section{Methods}

\section{SELECTION OF SUBJECTS}

Adult subjects were selected randomly by computer, as described elsewhere, ${ }^{5}$ and invited to attend a local health centre. Due to press publicity, a large number of people volunteered to be included. All socioeconomic groups were represented. The age range of the subjects was 19-88 years.

\section{BLOOD SPECIMENS}

These were taken from the subjects, who were not asked to fast, between 1815 and 2100 . Blood was taken from the antecubital vein with the subjects seated. A tourniquet was used only when necessary to locate the vein and released before withdrawal of blood. The blood was collected into tubes containing lithium heparin, and specimens were centrifuged and separated at the end of each session. The separated plasma was stored overnight for analysis the next day. The survey lasted for 13 months.

Received for publication 29 October 1979
ANALYTICAL METHODS

Total protein was measured by an automated Biuret method (Technicon method N 14a) and albumin by dye-binding with bromocresol green. ${ }^{6}$ Globulins were calculated by difference. Calcium was measured on a discrete analyser (Vickers D 300) using cresolphthalein complexone by a method adapted from Kessler and Wolfman ${ }^{7}$ and phosphate by reduction of phosphotungstate by ferrous ammonium sulphate. ${ }^{8}$ Urea was measured by autoanalyser, ${ }^{9}$ creatinine by Technicon autoanalyser method $\mathrm{N} 11 \mathrm{~b}$, and urate by an automated method adapted from Caraway ${ }^{10}$ and Crowley. ${ }^{11}$

\section{CALIBRATION}

The methods for calcium, phosphate, urea, creatinine, and urate were calibrated using primary aqueous standards prepared from analytical grade chemicals. Total protein and albumin standards were prepared from lyophilised human serum sold for use as quality control serum with values assigned by the manufacturer. After reconstitution, the total protein content was determined by measurement of total nitrogen (micro-Kjeldahl) and non-protein nitrogen using aqueous ammonium sulphate as primary standard. A factor of 6.25 was used to calculate protein from nitrogen content. The albumin value of the serum was assigned by electroimmunoquantitation using purified human albumin (Hoechst) dried over $\mathrm{CaCl}_{2}$ to constant weight as standard. This standardisation of calibration serum is necessary as we have found that the values assigned by the manufacturers are not always reliable.

QUALITY CONTROL OF THE METHODS

Two commercial lyophilised quality control sera 
Referencc ranges (95\%) for parameters studied, by age and sex

\begin{tabular}{|c|c|c|c|c|c|c|c|}
\hline & \multirow[t]{2}{*}{ Age (yr) } & \multicolumn{3}{|l|}{ Males } & \multicolumn{3}{|l|}{ Females } \\
\hline & & Median & $95 \%$ Range & $n$ & Median & $95 \%$ Range & $n$ \\
\hline Total protein $(g / 1)$ & $\begin{array}{r}20-29 \\
30-39 \\
40-49 \\
50-59 \\
60-69 \\
>69\end{array}$ & $\begin{array}{l}76 \\
76 \\
75 \\
75 \\
74 \\
75\end{array}$ & $\begin{array}{l}68-86 \\
67-86 \\
67-86 \\
67-82 \\
67-85 \\
67-84\end{array}$ & $\begin{array}{r}314 \\
523 \\
470 \\
291 \\
112 \\
36\end{array}$ & $\begin{array}{l}74 \\
74 \\
74 \\
74 \\
74 \\
76\end{array}$ & $\begin{array}{l}66-82 \\
66-83 \\
66-83 \\
66-83 \\
67-85 \\
67-84\end{array}$ & $\begin{array}{r}374 \\
695 \\
559 \\
278 \\
143 \\
50\end{array}$ \\
\hline Albumin (g/l) & $\begin{array}{r}20-29 \\
30-39 \\
40-49 \\
50-59 \\
60-69 \\
>69\end{array}$ & $\begin{array}{l}50 \\
49 \\
47 \\
47 \\
46 \\
45\end{array}$ & $\begin{array}{l}45-56 \\
43-55 \\
43-54 \\
41-53 \\
40-53 \\
41-52\end{array}$ & $\begin{array}{r}319 \\
524 \\
469 \\
293 \\
113 \\
36\end{array}$ & $\begin{array}{l}47 \\
47 \\
46 \\
46 \\
46 \\
45\end{array}$ & $\begin{array}{l}41-53 \\
41-52 \\
40-52 \\
40-52 \\
39-52 \\
39-51\end{array}$ & $\begin{array}{r}380 \\
695 \\
570 \\
281 \\
143 \\
49\end{array}$ \\
\hline Globulins (g/l) & $\begin{array}{r}20-29 \\
30-39 \\
40-49 \\
50-59 \\
60-69 \\
>69\end{array}$ & $\begin{array}{l}26 \\
27 \\
28 \\
28 \\
29 \\
29\end{array}$ & $\begin{array}{l}18-34 \\
19-36 \\
21-37 \\
20-36 \\
22-37 \\
22-39\end{array}$ & $\begin{array}{r}315 \\
520 \\
474 \\
294 \\
112 \\
36\end{array}$ & $\begin{array}{l}28 \\
28 \\
28 \\
27 \\
28 \\
31\end{array}$ & $\begin{array}{l}20-35 \\
20-36 \\
21-36 \\
20-36 \\
20-38 \\
22-38\end{array}$ & $\begin{array}{r}377 \\
692 \\
568 \\
277 \\
142 \\
49\end{array}$ \\
\hline Calcium (mmol/l) & $\begin{array}{r}20-29 \\
30-39 \\
40-49 \\
50-59 \\
60-69 \\
>69\end{array}$ & $\begin{array}{l}2 \cdot 40 \\
2 \cdot 40 \\
2 \cdot 40 \\
2 \cdot 40 \\
2 \cdot 40 \\
2 \cdot 35\end{array}$ & $\begin{array}{l}2 \cdot 20-2 \cdot 60 \\
2 \cdot 25-2 \cdot 60 \\
2 \cdot 20-2 \cdot 60 \\
2 \cdot 20-2 \cdot 65 \\
2 \cdot 20-2 \cdot 65 \\
2 \cdot 05-2 \cdot 65\end{array}$ & $\begin{array}{r}322 \\
549 \\
493 \\
299 \\
115 \\
39\end{array}$ & $\begin{array}{l}2 \cdot 40 \\
2 \cdot 40 \\
2 \cdot 40 \\
2 \cdot 45 \\
2 \cdot 45 \\
2 \cdot 45\end{array}$ & $\begin{array}{l}2 \cdot 20-2 \cdot 60 \\
2 \cdot 20-2 \cdot 60 \\
2 \cdot 20-2 \cdot 60 \\
2 \cdot 25-2 \cdot 65 \\
2 \cdot 25-2 \cdot 65 \\
2 \cdot 20-2 \cdot 70\end{array}$ & $\begin{array}{r}379 \\
692 \\
564 \\
279 \\
144 \\
50\end{array}$ \\
\hline Phosphate (mmol/l) & $\begin{array}{c}20-29 \\
30-39 \\
40-49 \\
50-59 \\
60-69 \\
>69\end{array}$ & $\begin{array}{l}1.15 \\
1.10 \\
1.10 \\
1.05 \\
1.05 \\
1.00\end{array}$ & $\begin{array}{l}0.80-1 \cdot 45 \\
0.75-1 \cdot 40 \\
0 \cdot 75-1 \cdot 40 \\
0 \cdot 70-1 \cdot 40 \\
0.70-1 \cdot 40 \\
0.60-1 \cdot 40\end{array}$ & $\begin{array}{r}317 \\
536 \\
489 \\
299 \\
115 \\
38\end{array}$ & $\begin{array}{l}1.05 \\
1.05 \\
1.05 \\
1.15 \\
1.10 \\
1.05\end{array}$ & $\begin{array}{l}0 \cdot 70-1 \cdot 40 \\
0 \cdot 70-1 \cdot 40 \\
0 \cdot 70-1 \cdot 40 \\
0 \cdot 80-1 \cdot 45 \\
0 \cdot 80-1 \cdot 40 \\
0 \cdot 80-1 \cdot 35\end{array}$ & $\begin{array}{r}385 \\
694 \\
564 \\
281 \\
145 \\
53\end{array}$ \\
\hline Urea (mmol/l) & $\begin{array}{r}20-29 \\
30-39 \\
40-49 \\
50-59 \\
60-69 \\
>69\end{array}$ & $\begin{array}{l}5 \cdot 5 \\
5 \cdot 5 \\
5 \cdot 5 \\
5 \cdot 5 \\
6 \cdot 5 \\
6.5\end{array}$ & $\begin{array}{l}3 \cdot 5-7 \cdot 5 \\
3 \cdot 0-8 \cdot 5 \\
3 \cdot 5-8 \cdot 5 \\
3 \cdot 0-8 \cdot 5 \\
3 \cdot 5-10 \cdot 0 \\
5 \cdot 0-10 \cdot 5\end{array}$ & \begin{tabular}{r|}
331 \\
549 \\
491 \\
300 \\
116 \\
37
\end{tabular} & $\begin{array}{l}4 \cdot 5 \\
5 \cdot 0 \\
5 \cdot 0 \\
5 \cdot 5 \\
6 \cdot 0 \\
7 \cdot 0\end{array}$ & $\begin{array}{l}2 \cdot 5-6 \cdot 5 \\
3 \cdot 0-7 \cdot 0 \\
3 \cdot 0-8 \cdot 0 \\
3 \cdot 5-8 \cdot 5 \\
3 \cdot 5-10 \cdot 0 \\
4 \cdot 5 \cdot 10 \cdot 5\end{array}$ & $\begin{array}{r}385 \\
703 \\
566 \\
291 \\
139 \\
50\end{array}$ \\
\hline Creatinine $(\mu \mathrm{mol} / \mathrm{l})$ & $\begin{array}{r}20-29 \\
30-39 \\
40-49 \\
50-59 \\
60-69 \\
>69\end{array}$ & $\begin{array}{r}90 \\
90 \\
90 \\
100 \\
100 \\
100\end{array}$ & $\begin{array}{l}60-110 \\
60-120 \\
60-130 \\
60-140 \\
70-140 \\
50-160\end{array}$ & $\begin{array}{r}321 \\
537 \\
476 \\
294 \\
116 \\
38\end{array}$ & $\begin{array}{l}70 \\
70 \\
80 \\
80 \\
80 \\
80\end{array}$ & $\begin{array}{l}50-110 \\
50-110 \\
50-110 \\
50-120 \\
50-120 \\
60-140\end{array}$ & $\begin{array}{r}384 \\
698 \\
560 \\
279 \\
142 \\
50\end{array}$ \\
\hline Urate $(\mu \mathrm{mol} / \mathrm{l})$ & $\begin{array}{r}20-29 \\
30-39 \\
40-49 \\
50-59 \\
60-69 \\
>69\end{array}$ & $\begin{array}{l}350 \\
350 \\
350 \\
330 \\
350 \\
330\end{array}$ & $\begin{array}{l}240-500 \\
240-520 \\
220-540 \\
220-500 \\
210-550 \\
200-520\end{array}$ & $\begin{array}{r}320 \\
539 \\
475 \\
295 \\
113 \\
36\end{array}$ & $\begin{array}{l}250 \\
240 \\
250 \\
280 \\
290 \\
330\end{array}$ & $\begin{array}{l}150-350 \\
150-360 \\
140-380 \\
150-410 \\
170-460 \\
160-500\end{array}$ & $\begin{array}{r}379 \\
697 \\
566 \\
283 \\
140 \\
50\end{array}$ \\
\hline
\end{tabular}

having high and low values of each constituent were included in each batch of samples. The mean between-batch coefficients of variation over the 13 months of the study were: total protein $1.5 \%$, albumin $2.6 \%$, calcium $2.0 \%$, phosphate $3.3 \%$, urea $2.9 \%$, creatinine $3.8 \%$, and urate $3.6 \%$. The laboratory also participated in regional, national, and Wellcome quality control schemes with satisfactory results, although the mean of the albumin results was consistently above the interlaboratory mean. This is thought to be due to the method of calibration.

\section{STATISTICAL METHODS}

Since it is uncommon for measured levels of plasma constituents to assume a Gaussian distribution we have chosen to use non-parametric methods, as discussed previously. ${ }^{5}$ This avoids the problem of finding mathematical manoeuvres to 'normalise' the values as no assumptions are made as to the form of the distribution. After arrangement of results by sex and by age groups within each sex, histograms of frequency were prepared and percent and cumulative percent frequency were calculated. The class intervals used were $1 \mathrm{~g} / \mathrm{l}$ for proteins, $0.05 \mathrm{mmol} / \mathrm{l}$ for calcium and phosphate, $0.5 \mathrm{mmol} / \mathrm{l}$ for urea, and $10 \mu \mathrm{mol} / 1$ for creatinine and urate. Results that were obviously pathological or extreme 'outliers' were removed but those omitted were less than $1 \%$ of the total in any group. Thereafter the frequencies were recalculated, and for preparation of reference ranges we followed the usual convention of taking $95 \%$ of 
the results, excluding the lowest and highest $2.5 \%$.

\section{Results and comparison with previous publications}

POPULATION OF SUBJECTS

Of the people randomly selected, 3397 aged 19-88 years attended and 622 volunteered. Results from both groups were combined. Results were arranged by sex and by age groups within each sex. The ages chosen were $20-29,30-39,40-49,50-59,60-69$, and $>69$ years, age being calculated to the nearest six months (results from three subjects aged 19 years were discarded, as was the occasional batch of results where the quality control was unsatisfactory). The numbers of subjects in each group and the reference ranges derived as described above are shown in the Table, and the distributions are given in Figure 1.

\section{TOTAL PROTEIN}

Our reference ranges are higher than many previously published, ${ }^{12-15}$ which may in part be explained by our use of plasma rather than serum. They agree well with those of Reed et al., ${ }^{16}$ who also used a nonparametric method of presentation. The present study confirms a slight decrease with age in the male population but shows the reverse in female subjects. Previous authors have not indicated the method used for standardisation. Morrison and Ballantyne (personal communication), in an unpublished study carried out in this department, have shown that between-laboratory variation of total protein and albumin can be largely attributed to the uncritical use of assayed commercial sera as calibration standards.

\section{ALBUMIN}

The reference ranges for this protein fraction were found to be higher than in most previous studies; this was presumed to be attributable mainly to our method of calibration. The fall of approximately $1 \mathrm{~g} / \mathrm{l} /$ decade in the male has been documented previously. ${ }^{13-17}$ We have found a lesser decrease with age in women than that shown by other authors.

\section{GLOBULINS}

These increase by about $0.6 \mathrm{~g} / \mathrm{l} /$ decade in male subjects while there is little change in females who have higher globulins than males in the younger age groups. Similar results were found by McPherson et al. ${ }^{15}$ although their results were approximately $3 \mathrm{~g} / \mathrm{l}$ lower as their measurements were made on serum.

\section{PHOSPHATE}

The results for male subjects are similar to those of Keating et al. ${ }^{13}$ and Reed et al. ${ }^{16}$ and show a con-

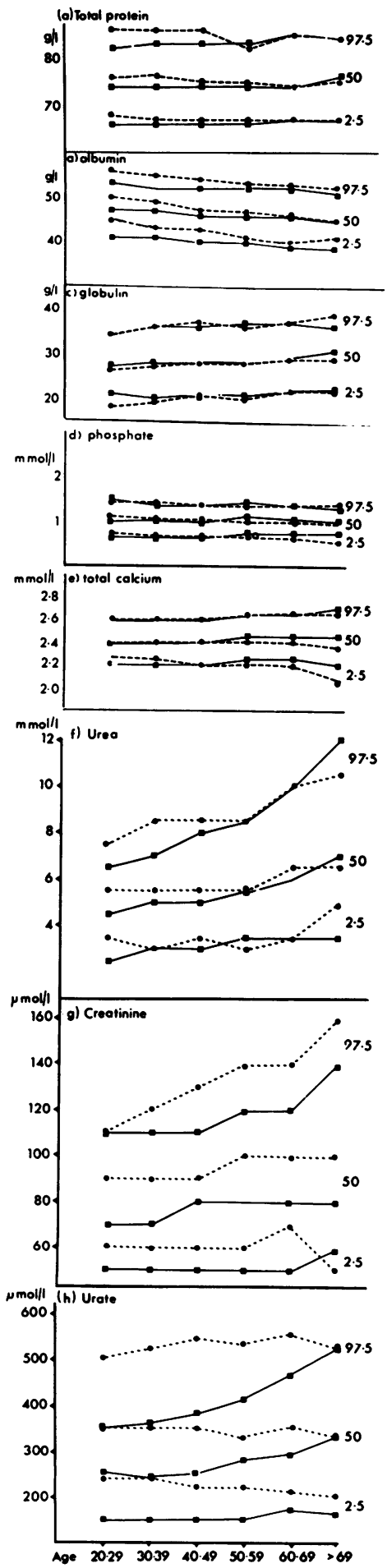

Fig. 1 Distribution of results of eight plasma constituents by age and sex showing $2 \cdot 5,50$, and 97.5 centiles: - - men; - women. 
sistent fall with age. This phenomenon was also demonstrated by Morgan ${ }^{18}$ and McPherson et al. ${ }^{15}$ but not by Wilding et al..$^{17}$ Female subjects show a small rise between the fifth and sixth decades (an observation already recorded by Keating et al., Wilding et al., and Reed et al.), but the postmenopausal rise is less than that found by Morgan or McPherson et al. As our subjects were not asked to fast before having blood taken our reference ranges must be accepted with some reservation but our figures are no lower than in other series where fasting subjects were used.

\section{CALCIUM}

The calcium median in men is unchanged throughout adult life until age $>69$ years but in women there is a postmenopausal increase, as described by Young and Nordin ${ }^{19}$ and McPherson et al. ${ }^{15}$

\section{UREA}

The distribution is positively skewed, especially in males and older women. Our results confirm both the sex difference and increase with age which have long been recognised. Median urea in the male increases by $1 \mathrm{mmol} / \mathrm{l}$ from the third to the seventh decades. The increase is much greater $(2.5 \mathrm{mmol} / \mathrm{l})$ in female subjects and is most marked in postmenopausal women. When compared with those of other authors using non-parametric methods of presentation, our reference ranges are slightly lower than those of Reed et al $^{16}$ and higher than those of Keating et al. ${ }^{13}$ Authors who have used parametric methods ${ }^{17}$ tend to underestimate the upper limit.

While preparing the frequency histograms for urea, we noticed that the distribution showed a 'bulge' at a cumulative frequency of about $90 \%$, which was most obvious in the groups containing the greatest numbers of subjects (Fig. 2) but occurred in both sexes and probably at all ages. The 'bulges' in the histograms might be caused by the presence of subpopulations, amounting to $2-3 \%$ of the whole, within the groups. These subpopulations might either be normal subjects whose plasma urea is maintained at a higher than 'usual' level or subjects with diminished renal function caused by disease. The level of urea at which the 'bulge' occurred increased with age and showed a sex difference in the same way as the population as a whole. The frequency histograms for creatinine did not show the 'bulge' phenomenon. This tends to support a postulated 'normal' subpopulation rather than a 'pathological' one as impaired renal function would tend to occur in the older subjects.

The case sheets of 269 subjects whose urea results lay under the apparent peak of each 'bulge' were examined to see if a common factor could be

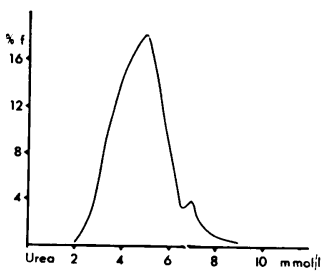

Fig. 2 Percent frequency distribution of urea in women aged 30-39 years.

elucidated. 'Smoothing' of the distributions by eye suggested that about two-thirds of the results would belong to the larger population and one-third to the putative subpopulation. In order to exclude analytical bias, the distribution of these results by date and batch number was studied, and they were found to be randomly distributed throughout the survey. The proportion of subjects born outside Scotland (approximately $8 \%$ ) or outside the British Isles (approximately $1 \%$ ) did not differ significantly between the selected subjects and the overall survey, thus excluding ethnic differences. We were unable, with the information available to us, to examine genetic differences which are known to influence urea levels. ${ }^{20}$

Fewer of the selected subjects had a previous history of renal disease or urinary tract infection, a current urinary tract infection, or symptoms such as dysuria, frequency, or incontinence than the population as a whole, while the proportion with a history of renal calculus disease was the same as that in the overall population.

We believe that there is a small number of people (other than those whose results lie in the tail of the distribution) whose urea level is maintained in health at a level above that which is 'usual', but we have been unable, with the information available from the survey, to establish a common factor.

\section{CREATININE}

Our results confirm the sex difference previously described by other authors. ${ }^{121517}$ The levels are similar to those of McPherson et al., ${ }^{15}$ who used a log transformation to 'normalise' their results, but are significantly higher than those of Wilding et al.,17 whose range is the mean \pm 2 standard deviations. Results in the oldest group agree fairly well with those of Leask et al., ${ }^{21}$ who also used log transformation. The increase with age is similar in both sexes and does not appear to be affected by the menopause, females having levels $20 \mu \mathrm{mol} / 1$ lower than males throughout the age groups studied. The age increase is probably due to loss of renal function with age, and from Fig. 1 it can be seen that the increase is largely accounted for by 'tailing' of the 
distribution as there are only minor changes in the $2 \cdot 5$ and 50 th centiles.

\section{UR A T E}

There is little change with age of the median value in male subjects but there is a tendency towards increasingly negative skew with increasing age. In the younger age groups male levels exceed those of females by about $100 \mu \mathrm{mol} / \mathrm{l}$. Results from female subjects are normally distributed at age 20-29 but skew positively with increasing age. The median shows little change until the menopause when it rises sharply towards the male value. Bengtsson and Tibblin ${ }^{22}$ and McPherson et al. ${ }^{15}$ have compared preand post-menopausal women of the same age and found no significant difference between their urate levels. They argue that the rise in urate found between the fifth and sixth decades cannot be attributed to the menopause. This rise has been found in previous studies. ${ }^{161723}$ It is difficult to attribute this increase to any factor other than loss of oestrogen.

\section{Discussion}

Many reference ranges in current use are ill defined, being derived from small numbers of healthy volunteers or hospital patients. The establishment of reference ranges poses many problems, particularly in the choice of subjects, and it is often difficult to examine large numbers of people and to standardise the conditions under which the specimens are taken. We are fortunate in having had a unique opportunity of taking blood from a random sample of the population of an entire town, and the size of our sample gives us confidence in our ranges except perhaps in the oldest group where the numbers are smaller. In presenting our ranges we are aware that we have not controlled some factors which may affect the results. Diurnal variation has not been measured since all the samples were taken in the evening. There were no obvious seasonal differences but these, if they exist, are unlikely to have affected the results since the survey lasted for 13 months. We have not studied the effect of racial, socioeconomic, or dietary factors or of prescribed drugs as our purpose was to reflect the condition of the population as a whole. We have no means of knowing if pathological results have been included as no subject was rejected on the grounds of ill health.

The increasing number of publications showing significant age and sex differences emphasise the need to take these into account when results from hospital patients are being evaluated. Ranges based on results from healthy young adults are becoming less appropriate as the age of hospital inpatients continues to increase. In general hospitals, it is common for more than one-third of the inpatients to be over 60 years and results from these patients must be viewed against those from individuals in the same age group.

We acknowledge the financial support of the Lanarkshire Area Health Board in this work and thank Mr Alan S McLelland for statistical advice and preparation of computer programs.

\section{References}

${ }^{1}$ Dybkaer R, Gräsbeck R. Theory of reference values. Scand J Clin Lab Invest 1973;32:1-7.

${ }^{2}$ Sunderman FW, Jr. Current concepts of "normal values", "reference values" and "discrimination values" in clinical chemistry. Clin Chem 1975;21: 1873-7.

${ }^{3}$ Winsten S. The ecology of normal values in clinical chemistry. CRC Crit Rev Clin Lab Sci 1976;6:319-30.

${ }^{4}$ Scott R, Freeland R, Mowat W et al. The prevalence of calcified upper urinary tract stone disease in a random population-Cumbernauld Health Survey. Br J Urol 1977; 49:589-95.

${ }^{5}$ Gardner MD, Scott R. Frequency distribution and 'reference values', of plasma alkaline phosphatase (EC 3.1.3.1) activity in the adult population of a Scottish new town. J Clin Pathol 1978;31:1202-6.

${ }^{6}$ Northam BE, Widdowson GM. Determination of serum albumin by autoanalyzer using bromocresol green. Association of Clinical Biochemists Technical Bulletin No 11, 1967.

${ }^{7}$ Kessler G, Wolfman M. An automated procedure for the simultaneous determination of calcium and phosphorus. Clin Chem 1964;10:686-703.

${ }^{8}$ Yee, HY. A simplified method for automated phosphorus analysis of serum and urine. Clin Chem $1968 ; 14: 898-903$.

${ }^{9}$ Haslam RM. Determination of urea by autoanalyser. Association of Clinical Biochemists Technical Bulletin No 9, 1966.

${ }^{10}$ Caraway WT. In: Seligson D, ed. Standard Methods of Clinical Chemistry. New York: Academic Press, 1963;4:239-47.

${ }^{11}$ Crowley LV. Determination of uric acid. Clin Chem 1964;10:838-44.

${ }^{12}$ Roberts LB. The normal ranges, with statistical analysis for seventeen blood constituents. Clin Chim Acta 1967;16:69-78.

${ }^{13}$ Keating, FR, Jr, Jones JD, Elveback LR, Randall RV. The relation of age and sex to distribution of values in healthy adults of serum calcium, inorganic phosphorus, magnesium, alkaline phosphatase, total proteins, albumin and blood urea. J Lab Clin Med 1969;73:825-34.

${ }^{14}$ O'Kell RT, Elliott JR. Development of normal values for use in multitest biochemical screening of sera. Clin Chem 1970;16:161-5.

${ }^{15}$ McPherson K, Healy MJR, Flynn FV, Piper KAJ, 
Garcia-Webb P. The effect of age, sex and other factors on blood chemistry in health. Clin Chim Acta 1978; 84:373-97.

16 Reed AH, Cannon DC, Winkelman JW, Bhasin YP, Henry RJ, Pileggi VJ. Estimation of normal ranges from a controlled sample survey. I. Sex- and agerelated influence on the SMA 12/60 screening group of tests. Clin Chem 1972;18:57-66.

17 Wilding, P, Rollason JG, Robinson D. Patterns of change for various biochemical constituents detected in well population screening. Clin Chim Acta $1972 ; 41: 375-87$.

18 Morgan B. Osteomalacia, Renal Osteodystrophy and Osteoporosis. Springfield, Illinois: C C Thomas, 1973.

${ }^{19}$ Young MM, Nordin BEC. Effects of natural and artificial menopause on plasma and urinary calcium and phosphorus. Lancet 1967;2:118-20.

${ }^{20}$ Havlik R, Garrison R, Fabsitz R, Feinleib M. Genetic variability of clinical chemical values. Clin Chem 1977;23:659-62.

${ }^{21}$ Leask RGS, Andrews GR, Caird FI. Normal values for sixteen blood constituents in the elderly. Age Ageing $1973 ; 2: 14-23$.

${ }^{22}$ Bengtsson C, Tibblin E. Serum uric acid levels in women. Acta Med Scand 1974;196:93-102.

${ }^{23}$ Mikkelsen WM, Dodge HJ, Valkenburg H. The distribution of serum uric acid values in a population unselected as to gout or hyperuricemia. Am J Med $1965 ; 39: 242-51$.

Requests for reprints to: Miss Mary D Gardner, Department of Biochemistry, Royal Infirmary, Glasgow, G4 OSF, UK. 